\title{
On the Risks and Solutions of the Bank Depository in P2P Client Funds
}

\author{
Guilin Gao \\ Law School \\ Capital University of Economics and Business \\ Beijing, China \\ gaoguilinrenda@163.com
}

\author{
Changchao Hou* \\ Law School \\ Capital University of Economic and Business \\ Beijing, China \\ houchangchaolaw@163.com
}

\begin{abstract}
In accordance with the law, the funds obtained from the clients of P2P network platform in China must be deposited with the bank. However, the bank depository of the customer funds can't really solve the platform's control of customer funds, and the fund pool and self-financing can be completed indirectly, which is not conducive to the development of the industry. This paper analyzes the real difference between China depository and trusteeship is the real review of P2P loan platform by empirical analysis of the depository and using comparative analysis method. Based on this, the client funds should be managed by the bank, only in this way can the industry's credibility be improved and keep the client's funds safe.
\end{abstract}

Keywords—Network loan platform; Client's funds; Bank depository

\section{INTRODUCTION}

On August 17, 2016, "Interim Measures for the management of business activities of intermediary agencies of online lending information" were formally promulgated in China (hereinafter referred to as the" interim measures "), in order to guard against the network lending information intermediaries to establish their own pool of funds, contrary to the legal status of their information intermediary, and the legislation enacted a number of measures, including the article 28: "The network loan information intermediary institution should implement the isolation management of the funds of itself and the funds of lenders and borrowers, and choose the eligible banking financial institutions as the lender and the borrower's depository institutions", which is one of the most powerful measures against this risk, and it abolish the original deposit of funds by itself and the deposit of funds by thirdparty affiliated platforms in the form of law so that the banking industry as the only legal capital depository place. However, according to the incomplete statistics of Research Institute 01, as of December 8, 2016, there were 1,620 normal operating network loan platforms in China, only 124 companies that have completed the bank's depository system online, accounting for $7.7 \%$ of the normal operating platforms. [1] The government has given 12 months to reorganize, but for nearly 4 months, the probability of meeting the requirements is so low, so we have to rethink whether it is the solution that P2P client funds are deposited by banks.

\section{OVERVIEW OF THE DEPOSIT MANAGEMENT OF P2P CLIENT} FUNDS

\section{A. The explosive growth of $\mathrm{P} 2 \mathrm{P}$ network loan platform in China}

PPDAI, the first P2P loan platform in China, was established in August 2007, [2]but it really began to grow rapidly in 2015. At the end of June 2016, there were 2,349 net loan institutions operating in China, with a loan balance of 6212.61 billion yuan, the two figures of which rose 49.1 percent and 499.7 percent respectively from the end of 2014. [3]But China's P2P loan platforms grew rapidly due to the rapid growth of China's economy, and more importantly, it violated the initial positioning of P2P loan platform and breaks through the restrictions, which also laid a hidden danger for the phenomenon such as the chaos of P2P loan institutions, running-away platforms could be found everywhere. As a result, the "interim measures" put forward the strategy that P2P client funds should be maintained and managed by the bank depository.

\section{B. Definition and practice of bank depository}

Because of the non-standard of the P2P industry, the "interim measures" has introduced the measures for the bank depository of funds from investors, according to the provisions of article 2 of the "Guidelines on the depository of online loan funds" on February 22, 2017: the depository is refers to the commercial bank as depository party accepting the entrust of the clients to perform the business of opening and cancelling accounts, keeping funds, checking accounts and providing information reports for special account of network loan fund depository in accordance with the laws and regulations and the contract. The depository shall carry out the deposit business of network loan fund, and shall not provide warranty or guarantee the activity of online loan and loan, and shall not be liable for the loan default.

As the depository institution, the bank is the only funds depository place the regulators unequivocally support. In practice, the investors usually register P2P platform users, open a platform account, and jump to the page to open a bank account; the bank accounts are associated with $\mathrm{P} 2 \mathrm{P}$ platform account one by one. When investors invest, the money is transferred directly to the bank account of the P2P operator 
through its own bank account. However, unlike the bank account of the P2P platform operator who does not carry out bank custody, the managed account will open a sub-account for each platform user. So in theory, the money is transferred from the bank account of the investor to the bank sub-account of the secondary bank under the bank account of the P2P platform. This requires the $\mathrm{P} 2 \mathrm{P}$ platform to separate the platform's own funds from the customers' funds clearly, and each transaction and transfer in the account is to be operated by the bank and provide data to prove its trend.

In the bank depository business, it is the P2P loan platform that deals with Banks. It is not hard to find that the bank depository does not really prevent the platform from contacting with investors, and all of the money invested and transferred will need to go through P2P loan platform, as a result, for the false bid, self-financing (Self-financing is mainly based on platform shareholders or shareholders-affiliated enterprises as borrowers to borrow money from investors, and the collected funds are used for the development of the platform itself or related enterprises ) or capital pool, etc., if the P2P platform wants to do it or can do it, then we will analyze the risks.

\section{THE RISK OF P2P CLIENT FUNDS FROM BANK DEPOSITORY}

First of all, from the bank's point of view, the first is that the banks are unwilling to bear too high depository costs. In order to realize the depository and management of funds, banks must specially rebuild a set of systems. Most of the banks are not willing to take over the depository business because of the time, energy and cost are too high, which is clearly reflected in the recent bankers' answers to reporters' questions; the second is that the bank will not bear the reputation risk for the P2P platform. At the beginning of 2016, many P2P platforms with media influence plunged into the Ponzi scheme and illegal fund-raising whirlpool, the entire reputation of P2P industry fell to the bottom, Considering the reputation risk, large banks have been cautious about the development and promotion of their own depository system, or suspended the service, which is why Minsheng bank has gradually terminated the cooperative relationship with some of the cooperative platforms. The "interim measures" regulation of the depository seems to be a constraint on the online loan platforms, but on the other hand, because of the chaos of online loan platform, the implementation of this regulation is a kind of government support to the P2P industry. Through this series of measures, it can regain investors' confidence in the $\mathrm{P} 2 \mathrm{P}$ industry, the money depository means that the bank will not undertake any collateral or risk to the industry, so P2P loan platforms can't still get out of the bottom of their credibility.

Thirdly, the uncertainty of policy causes bank depository to become a mere formality. There is no precedent in other financial sectors for the technical standards of depository, In addition, the "Interim Measures" issued for bank custody, at the regulatory level, the technical standards for P2P funds deposited in banks have not been formulated, In case the depository system built at this time does not meet the regulatory requirements, it is likely to be overturned, so it is the uncertainty of industry rules that also affects the speed at which P2P platforms are connected to bank depository.
Finally, the most important thing is that the bank deposit cannot really solve the problem of establishing pools of funds and illegal financing of P2P loan platforms. [4]Bank custody of funds for the $\mathrm{P} 2 \mathrm{P}$ platform, to a certain extent, can prevent the $\mathrm{P} 2 \mathrm{P}$ network loan platform to control the investor's funds, but we can see that the depository business includes only the opening and closing accounts, fund custody, capital settlement, reconciliation, providing information reporting through the definition of depository of "Guidelines on the Business of Online Loan Funds". These duties are more appropriate to call "deposit" than "storage", the most important point is that the bank does not have the "management", which precisely should be the important adjustment to the $\mathrm{P} 2 \mathrm{P}$ loan platform. In view of the current depository rules, when the platform establishes a capital account for transaction verification and transfer settlement, the account is generally in a regulatory vacuum. In theory, banks can operate and supervise this account, but because there is no specific regulatory standards, banks generally only allow platforms and individuals to open an account, and do not undertake the responsibility of operation and supervision. The capital account is opened by the platform, and the platform can actually control the funds in the account independently. Under the condition that the capital accounts are not supervised, the risk of misappropriation of funds and disappearance with the money always exists and the banks will not verify transactions and will not monitor the use of funds. Suppose that the platform first obtains funds from the investors and then lends it to the Lenders, in this process, the formation and transfer of precipitation funds are out of supervision, the illegal fund-raising behavior may not be found and stopped in time, because the bank will not verify the authenticity of the transaction, and the platform has indirectly realized the purpose of illegal fund-raising. Therefore, only the provisions of bank custody, but no relevant supporting regulatory measures, may lead to serious financial fraud, illegal fund-raising and a variety of moral hazard issues, which will bring huge losses to investors, and eventually make the industry into chaos and disorder.

Therefore, bank capital deposit is a great firewall to ensure the security of P2P investment. However, even if it is officially connected to a bank, the absolute security of user funds and their projects cannot be guaranteed. The financial security of P2P platform depends on the operation, internal control and moral rules of the platforms. The investors should investigate the compliance and security of the platform from many aspects instead of focusing on whether the P2P has realized the bank depository.

\section{THE ASSUMPTION TO SETTLE THE RISK OF BANK DEPOSITORY}

\section{A. Depository and trusteeship}

Through the above bank custody risk, we can draw the conclusion initially; we need to make the improvement measures have certain technical standards and regulatory standards, so it is best to have a precedent in our country to complete the safety transition of China's P2P industry reorganization. The most important thing is to make the banks to play a supervisory role to prevent $\mathrm{P} 2 \mathrm{P}$ platform from 
establishing pool of funds and illegal fund-raising. And such measures can easily be inspired by the measures taken by banks to manage the funds of securities industry.

The deposit of securities funds in banks is managed by trusteeship, and it is explicitly stipulated in the article 58 of "Regulations on Supervision and Administration of Securities Companies": Securities companies which are engaged in securities asset management business shall entrust their client's entrusted assets to a commercial bank or other asset custody institution recognized by the securities regulatory agency under the state council. As for trusteeship, the definition of bank trusteeship in "Guidelines for the Trusteeship of Clients' Funds of Commercial Banks” is as follows: the trusteeship of clients' funds means that commercial banks accept clients' entrust as trustee, and perform the functions of safekeeping customer funds, handling funds, supervising the use of funds, disclosing funds and using information in accordance with the provisions of the laws and regulations and the contract to guarantee the special funds for customers, improve efficiency, prevent risks, and improve the credit of the asset management business.

From the definition of depository and trusteeship we can easily see the difference between them: The trusteeship also includes supervision of the use of funds, in addition to depository funds including custody funds, liquidation and other business, and the supervision of funds is reflected in the supervision of the investment behavior of securities companies, and it is precisely this supervisory action that constitutes the most essential difference between depository and trusteeship. The P2P funds have been passed through the banks by the bank depository, however, as the bank is only responsible for the collection, preservation and transfer of funds, there is no substantive review of the process. So the essence of P2P capital bank deposit is that $\mathrm{P} 2 \mathrm{P}$ loan platforms have transformed the funds into the place of preservation. Compared with the law before the bank depository, it is only that the bank has kept all the transaction records to facilitate the inquiry. But the convenience of inquiry does not reduce the risks, even if the government regulatory authorities found the violations of $\mathrm{P} 2 \mathrm{P}$ network loan platforms, and to review the banks, it may be too late. And P2P funds managed by the banks means that banks play a role in financial supervision to some extent, and it can supervise every transaction of the P2P platforms, which makes the banks, turn from passive acceptance to active scrutiny. Some scholars have put forward the deposit account and the trust account, and make a distinction between the degrees of the distribution rights of the client funds by the online loan platforms. The depository account is considered to be a "restricted account" and the trust account is a "strictly restricted" account. [5]But the author thinks that the right of control and the right of supervision of the banks are two aspects of the same thing. When the supervision power of the bank is large, the scope of the bank can be reduced naturally, so the two statements are actually similar to each other.

Therefore, there are two legal relationships between P2P loan platforms and Banks in the custody business of customer funds. First: when P2P loan platforms entrust client funds to Banks, the two parties have formed an equal trust relationship in the civil law, and the P2P loan platform is the custodian, while the bank is the trustee, responsible for keeping the funds and handling the liquidation and so on; Secondly, there is a legal relationship between supervising and being supervised, if the trusteeship business can be established between the P2P loan platforms and the banks, the supervision right of the banks comes from the authorization of the law. At this time, the bank replaces the responsibilities of China's financial supervision department and exercises supervision over the use of P2P loan platforms for funds, which means that the banks can check the authenticity of the cash flow. For P2P loan platforms, it no longer has full control over the client's funds.

\section{B. Benefits of the bank trusteeship of P2P client funds}

First of all, bank custody greatly saves the manpower and material resources of the financial supervision department. Banks have a natural advantage in monitoring the funds on the P2P loan platform, no matter whether the P2P online loan platform is managed by the bank or not, the funds will be kept in the bank. In the current era of e-commerce, all the funds are basically through the bank's account for circulation. It is difficult for the government and financial regulators to verify the funds transactions one by one, however, banks can monitor the use of funds in real time and issue reports to the public due to the flow of funds. And Banks have had the precedent of implementing custodial business in the securities industry, fund industry and other industries, and they are familiar with the business process, and the cost is relatively smaller than the financial supervision department.

Secondly, P2P client funds managed by banks can effectively prevent the $\mathrm{P} 2 \mathrm{P}$ platforms from controlling funds and indirectly realizing illegal financing. According to the previous article, banks can monitor the use of P2P loan platform funds, which is different from the "inaction" of banks during the depository period, and the trusteeship enables banks to play a key role in the relationship of three parties, the dominance of P2P loan platforms has been reduced infinitely. Because each transaction needs to go through the bank's substantive review, and the amount of transactions on the network loan platform is smaller than that of other financial institutions, the probability of the illegal operation of P2P loan platform has been reduced and the illegal financing of P2P loan platform has been effectively regulated.

In the end, objectively speaking, the real meaning of bank custody is to realize the effect of increasing credibility. For P2P loan platforms, being trusted by their investors and borrowers is the basis of their business of P2P loan platform. But by the end of June 2016, there were more than 1,700 platforms in China, accounting for $43.1 \%$ of the total number of national institutions. The network loan platform industry temporarily falls into the doldrums, it is difficult to obtain public trust, P2P industry has suffered a devastating blow. At this time, the "interim measures" were introduced to standardize the operation of the industry and regain the trust of the public to the online loan platform, but the credit growth of the network loan platform is limited. Due to its failure to effectively prevent the illegal financing of the online loan platform, the platform running-away with money occurred once again. The result will not be a distrust of online loan platforms, but also a distrust of the banks that are not supposed to be responsible in the depository system. [6]In addition, as the public's understanding 
of the financial industry continues to deepen, they more understand that the constraint of the depository on the P2P loan platform is so small. However, in the trusteeship system, because the bank assumes the supervision responsibility for the funds entrusted by the P2P loan platform, to some extent, it is the self-supervision that supports the credibility of the network loan platforms. After all, for lenders and platforms, the banks are the third party without interests. And the bank has experience to be engaged in trusteeship business in the securities industry and the fund industry and the circulation of funds in securities industry and fund industry is relatively safe, which also provides a foundation of trust for lenders to have creditor-debtor relationship through the network loan platforms to some extent.

\section{CONCLUSION}

The promulgation of "interim measures" provides a clear solution to the most difficult financing problem in the $\mathrm{P} 2 \mathrm{P}$ industry, but the solution of depository is only in view of the present phenomenon at that time, which doesn't not completely solve the fundamental problem of network loans industry, and the platform can still use fraud and other means to establish fund pools, and this measure builds confidence for the public which is really false. Once in the case of running away with money, bankruptcy on the platform, the lenders' money can't still be guaranteed. Therefore, it is important to give full play to the supervision role of the bank and adopt trusteeship way to supervise the use of the platform funds.

\section{REFERENCES}

[1] http://p2p.hexun.com/2017-01-03/187588623.html,May 15, 2017

[2] Song Jie,Risk control and legal supervision of network loans, Law Tress, 2016, pp69-73, (In Chinese) The new financial research center of China finance and economics, The white paper on China's loan services industry, China Economics Press, 2013, (In Chinese).

[3] http://www.cbrc.gov.cn/chinese/home/docView/A7361C1732D746E0A E28538D0FEFB840.html,September 20, 2017.

[4] Yang Zhenneng: Legal analysis and regulatory research on the operation behavior of P2P online loan platforms, Research on Financial Regulation, the 11th issue, 2014. (In Chinese).

[5] Liu Yingsheng: Customer capital management of P2P institutions, China Finance, the 18th issue, 2014. (In Chinese).

[6] "Interim Measures for the management of business activities of intermediary agencies of online lending information”, http://www.cbrc.gov.cn/govView_37D312933F1A4CECBC18F9A9629 3F450.html 